\title{
Individual predispositions and positive adaptation of children of alcoholics
}

\author{
Iwona Grzegorzewska \\ Laboratory of Psychology, Department of Sexuology, Counselling and Resocialization, \\ University of Zielona Góra, Poland
}

\section{BACKGROUND}

Children of alcoholics have been the focus of both clinicians and scientists for years. Recent research undertaken from the perspective of developmental psychopathology has shown considerable variation of the investigated population, with clear emphasis on positive adaptation as the target developmental result. The aim of this study was to determine whether children of alcoholics showing positive adaptation are characterized by a specific system of individual predispositions.

\section{PARTICIPANTS AND PROCEDURE}

The study involved 540 individuals in three age groups and two comparison groups: children of alcoholics and children from the control group. The research model assumed risk assessment, assessment of positive adaptation and estimating individual predispositions that are important from the point of view of the problem.
RESULTS

The results confirmed the hypothesis that children of alcoholics cope well with the developmental requirements, and - despite the number of adverse life circumstances - are featured by a more favourable combination of individual predispositions.

\section{CONCLUSIONS}

The population of children of alcoholics is varied. Accordance with the multifinality, in addition to clear susceptibility to psychopathology, characterized by a positive adaptation, dependent on personality factors.

\section{KEY WORDS}

developmental results; alcoholism; resiliency; temperament; attachment

CORRESPONDING AUTHOR - Iwona Grzegorzewska, Laboratory of Psychology, Department of Sexuology,

Counselling and Resocialization, University of Zielona Góra, 2 Energetyków Str., 65-001 Zielona Góra, Poland, e-mail: I.Grzegorzewska@wnps.uz.zgora.pl

aUthors' Contribution - A: Study design - B: Data collection - C: Statistical analysis - D: Data interpretation .

E: Manuscript preparation · F: Literature search · G: Funds collection

to Cite this ARTICLE - Grzegorzewska, I. (2013). Individual predispositions and positive adaptation of children

of alcoholics. Current Issues in Personality Psychology, 1, 11-25. 


\section{BACKGROUND}

Children of alcoholics have been the centre of attention of both clinical psychologists and scientists for years. This is due, on the one hand, to the high incidence of the problem of alcoholism in society, and on the other hand, to the specificity of the functioning of families with alcohol problems. According to the Polish State Agency for the Prevention of Alcohol Related Problems, in Poland about 800 thousand people are addicted to alcohol, which gives an estimate of the number of children of alcoholics at about 1.5 million (PARPA, 2012).

Our knowledge about children of alcoholics is growing constantly. Nowadays we know that the offspring of addicted parents are, on the one hand, more susceptible to various problems, including alcoholism, and on the other hand, some children of alcoholics develop correctly, leading a satisfying life free from serious disorders.

The increased susceptibility of children of alcoholics has biological and psychological-social roots. Biological susceptibility results from genetically conditioned problems in that population. However, one single gene responsible for alcoholism has not been identified yet, which would become a spectacular and exciting event in the field of research on addictions. The complexity and diversity of the phenotypic image of alcoholism, in principle precludes the existence of a specific location of a gene responsible for the disorder associated with alcohol abuse. Nevertheless, progress in mapping the human genome is bringing us closer to the relationship between the structure of chromosomes and the metabolism of alcohol in the organism (e.g. Higuchi et al., 1992), a relationship which has a significant impact on drinking behaviours.

The second source of susceptibility comes from psychosocial factors, which enhance the life distress and induce indirectly problematic behaviours among children of alcoholics. Therefore, from this perspective, susceptibility results from specifically alcohol-related and specifically alcohol-unrelated influence exerted by parents on their offspring (Jacob \& Johnson, 2000). Specifically alcohol-related effects are connected with the unconscious identification and modelling process, copying parents' drinking patterns, developing expectations related to alcohol consumption and some aspects of the parent-child relation (Chassin et al., 1993; Webster et al., 1989; Zucker, Kincaid, Fitzgerald \& Bingham 1995). They are especially significant in terms of the development of addiction among children of alcoholics. Meanwhile, the specifically alcohol-unrelated influence refers to the more general features of the family environment, e.g. insufficient fulfilment of the parental role, dysfunctional patterns of the parent-child relation and coexistent mental disorders of parents. They are all risk factors that increase the probability that children of alcoholics will develop any of the whole spectrum of mental disorders and behaviours not compliant with social norms, including alcoholism. It is primarily about alcoholism associated with antisocial personality and secondary depression-related alcoholism (Ellis, Zucker \& Fitzgerald, 2000). Although studies conducted within both fields apply different procedures and focus on different research objectives, their authors (e.g. Ellis et al., 2000; McGue, 2000) agree that individual susceptibility of children of alcoholics to the development of disorders is the result of interacting genetic and environmental factors.

The increasing number of studies conducted on the population of children of alcoholics is improving the understanding of the development, and the conditions of this development, of addicted parents' offspring. Research conducted from the perspective of developmental psychopathology has led to the discovery of the resilience phenomenon among children of alcoholics. The concept of mental resilience explains the phenomenon of positive adaptation among young individuals exposed to unfavourable life events. This concept explains primarily the significance of factors and protective mechanisms, and their impact on the final developmental results. There is a definite terminological differentiation in the literature of the subject, concerning the concept of resilience (see Kaplan, 2005); nevertheless, the majority of researchers are inclined to consider this concept not as a stable feature of a child, but as a multifactorial, dynamic process of coping with unfavourable developmental conditions, which leads to positive adaptation (Luthar, Cicchetti \& Becker, 2000; Borucka \& Ostaszewski, 2008). Positive adaptation is one of the key terms crucial for understanding the development of children brought up in unfavourable living conditions. It refers to a multi-dimensional process in which an individual uses their mental abilities and environmental resources to adjust well to the requirements of subsequent developmental phases. Positive adaptation is considered to be the product of mutual interaction between individual (biological and psychological) characteristics of a person and his/her former adaptation process and current developmental context (Boyce et al., 1998; Sroufe, 1997; Cicchetti, 2006). Positive adaptation is therefore one of the possible developmental outcomes with children of alcoholics.

Achievement of positive adaptation would not be possible without the impact of protective factors, which support young individuals in avoiding negative risk effects. The characteristic feature of protective factors is the modified response of a person to a risky situation. Personality resources are a significant source of positive adaptation for children of alcoholics (Cierpiałkowska, 2010). Personality traits 
combined with environmental resources determine the extent to which an individual is able to function in a positive and competent way despite increasingly unfavourable living conditions.

Taking the above into consideration, the aim of the presented research was to answer two basic questions: (1) do children of alcoholics demonstrate positive adaptation despite experiencing chronic life distress, and (2) are there differences between children of alcoholics with high and low levels of adaptive functioning in terms of the measured individual predispositions?

\section{PARTICIPANTS AND PROCEDURE}

\section{PARTICIPANTS}

The research project included 540 children divided into two comparative groups (children of alcoholics and children of non-alcoholics) and three age groups: school age (9-12 years), adolescence (13-16 years) and late adolescence (17-20 years).

The clinical population included children and adolescents from families with an alcohol problem, differentiated on the basis of the screening test CAST. A total of 267 individuals were examined $(90,88,89$ subjects per each age group, respectively). The control group consisted of 273 individuals from families without an alcohol problem (headcount respectively: $92,90,91)$. The groups had a similar distribution in terms of gender. Each person qualified to the study had to fulfil certain criteria that were significant due to the applied research model. In the alcohol group the criteria were as follows: 1) father's alcoholism; 2) complete family; and 3) subject's parents did not report any other psychopathological symptoms (apart from the addiction). Subjects were qualified to the control group on condition they met the following criteria: 1) being brought up in a complete family; and 2) no mental disorders, including alcohol addition, with subjects' parents. The control group was formed on the basis of stratified probability sampling among pupils.

\section{PROCEDURE}

The study was conducted individually or in small groups. Individuals were recruited to the project through addiction treatment centres, community centres and school pedagogues. The research procedure consisted of two phases. After qualifying the adolescents to the study, obtaining their consent and the consent of minors' parents, the main part of the research project started. The subjects received a set of questionnaires to fill in, which measured the investigated variables.

\section{VARIABLES}

An expression of the adaptation of children of alcoholics (dependent variable) was given by the level of their mental health, as measured by four indicators: 1) externalization of problems, 2) internalization of problems, 3) developmental tasks and 4) a sense of satisfaction with life. Individual predispositions, including personality (independent variables), included: temperament, attachment, psychological resilience and coping with stress.

\section{RESEARCH TOOLS}

Tools used in the research project included: tools to measure criterion variables - risk (a family with an alcohol problem); dependent variables - positive adaptation; and independent variables - individual predispositions.

\section{RISK ESTIMATION}

Screening test CAST (Jones, 1983).

\section{POSITIVE ADAPTATION ESTIMATION}

Externalisation and internalisation of problems: the Achenbach Child Behaviour Checklist (CBCL) (Wolańczyk, 2002); Attainment of developmental tasks: the Developmental Tasks Attainment Questionnaire (Grzegorzewska, 2006); Sense of life satisfaction: the Brief Multidimensional Students' Life Satisfaction Scale (BMSLSS) (Huebner, Seligson, Valois, 2003).

\section{INDIVIDUAL PREDISPOSITIONS ESTIMATION}

Psychological resiliency: the Resiliency Scales for Children and Adolescents (Prince-Embury, 2007). Temperament: the EAS Temperament Survey by A.H. Buss and R. Plomin, Polish adaptation by W. Oniszczenko (1997). Attachment: two subscales of the Inventory of Parent and Peer Attachment (IPPA) (Armsden \& Greenberg, 1987). Coping with stress strategies: the 'How are you doing?' scale by Zygfryd Juczyński and Nina Ogińska-Bulik (JSR; 2009).

\section{RESULTS}

In order to answer the research questions, the statistical analysis of the results included: 1) the division of subjects into two groups with odd health profiles using cluster analysis and the $k$-means technique, and determining the probability of classifying children of alcoholics to the high adaptive functioning 
profile using the odds ratio technique; 2) determining whether children of alcoholics with a high adaptive functioning profile differ from those with a low level of adaptive functioning profile in terms of the measured individual predispositions.

\section{POSITIVE ADAPTATION OF CHILDREN OF ALCOHOLICS}

The first step in the analysis was to determine how the subjects dealt with adjusting to developmental and living conditions. To do this, the subjects were divided into two groups with different health profiles, using the $k$-means clustering technique. The profiles were differentiated on the basis of four quantitative variables characterising mental health: 1) externalization of problems, 2) internalization of problems, 3) developmental tasks and 4) a sense of satisfaction with life. The analysis of the main components revealed that four of them are significant: high and low level of adaptive functioning. Profile 1 (high level of adaptation) characterizes individuals who achieved high results in the four measured aspects of mental health and demonstrate good adjustment and adaptation. They are featured by better attainment of developmental tasks and lower intensity of psychopathological symptoms. Profile 2 (low level of adaptation) characterizes individuals who achieved lower results in the four measured aspects of mental health and are featured by higher intensity of psychopathological symptoms and demonstrate poor adjustment and adaptation. The frequency distribution of the profiles differentiated in the control group and the clinical population, taking into consideration the age of subjects, is presented in Table 1.

As can be concluded from the presented table, in all age groups the majority of individuals in the risk group (children of alcoholics) have a low-level adaptation profile, and a high-level adaptation profile in the control group. The smallest difference in the population size occurs in the adolescence period. The high-level adaptation profile features $38.9 \%$ of children of alcoholics in school age and $65.2 \%$ of children from the control group; $40.9 \%$ of adolescent children of alcoholics and $64 \%$ of adolescents from the control

Table 1

Frequency distribution of the differentiated adaptation profiles in the control group and clinical population, taking into consideration the age of subjects

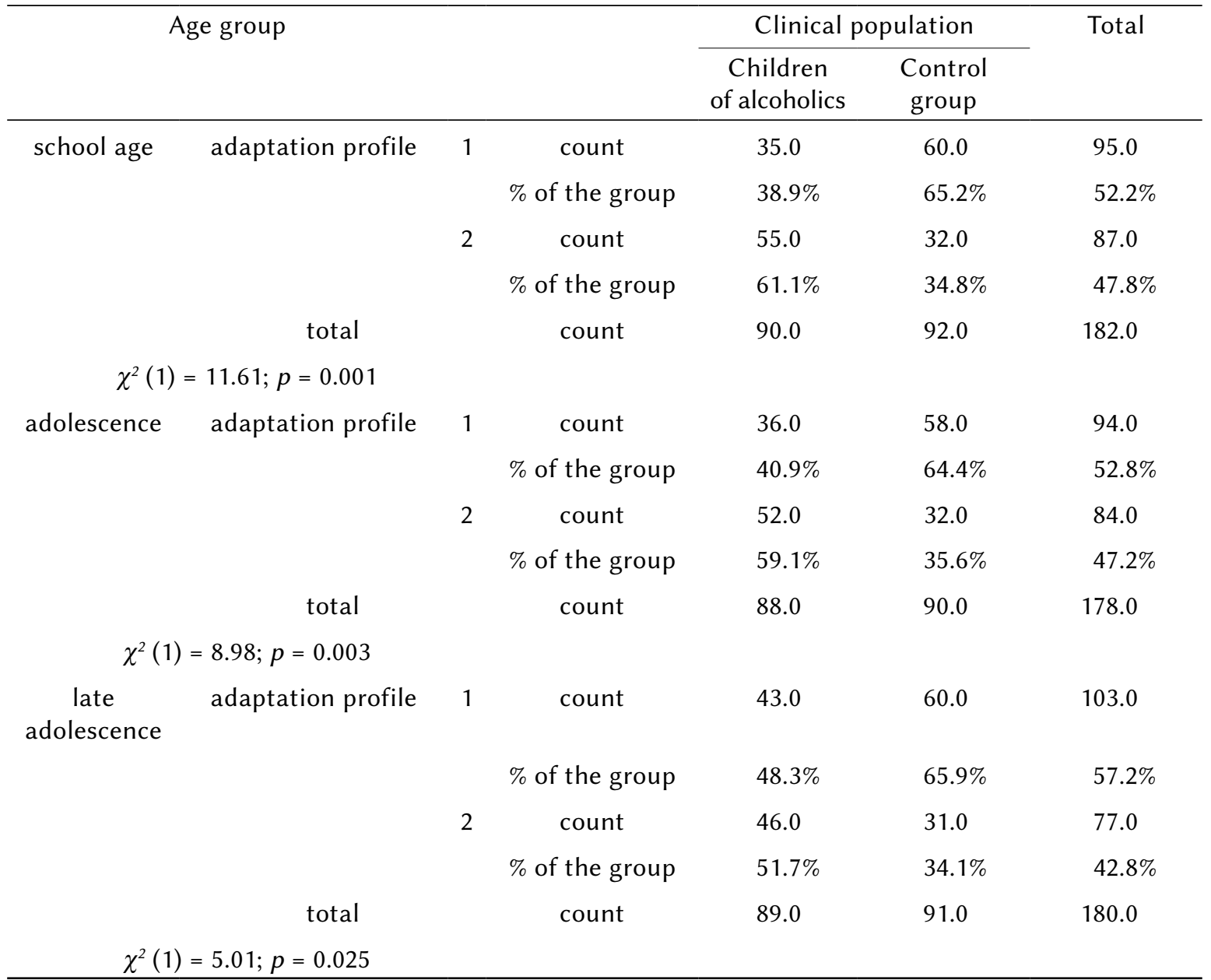


Iwona Grzegorzewska

Table 2

The ratio of chances for qualifying the subjects to the high-level adaptation profile

\begin{tabular}{|c|c|c|}
\hline & Children of alcoholics & Children from the control group \\
\hline School age & $\begin{aligned} O R & =0.58 \\
95 \% \mathrm{Cl} & =0.34-0.97\end{aligned}$ & $\begin{aligned} O R & =1.7 \\
95 \% \mathrm{CI} & =1.02-2.88\end{aligned}$ \\
\hline Adolescence & $\begin{aligned} O R & =0.62 \\
95 \% \mathrm{Cl} & =0.37-1.04\end{aligned}$ & $\begin{aligned} O R & =1.62 \\
95 \% \mathrm{Cl} & =0.96-2.73\end{aligned}$ \\
\hline Late adolescence & $\begin{aligned} O R & =0.7 \\
95 \% \mathrm{Cl} & =0.42-1.63\end{aligned}$ & $\begin{aligned} C R & =1.45 \\
95 \% \mathrm{Cl} & =0.86-2.44\end{aligned}$ \\
\hline
\end{tabular}

group; $48 \%$ of late adolescents from alcohol problem families and $65.9 \%$ of those from the control group. The low-level adaptation profile features $61.1 \%$ of children of alcoholics and $34.8 \%$ of those from the control group; $59.1 \%$ of adolescent children of alcoholics and $35.6 \%$ of those from the control group; and $51.7 \%$ of late adolescent from alcohol problem families and $34.1 \%$ of those from the control group.

If a father abuses alcohol in the family of a child in school age, the ratio of the child's chances to qualify to the high-level adaptation profile (profile 1 was $O R$ (odds ratio) $=0.58$ and 95\% CI (confidence interval) $=0.34-0.97$, and in the case of children from families without the alcohol problem, the chances indicator was $O R=1.7$, and 95\% CI $=1.02-2.88$ (see Table 2). For adolescent children of alcoholics, the chances indicator was $O R=0.62$ and $95 \% \mathrm{CI}=0.37-1.04$, and for adolescents from the control group it was $O R=1.62$ and $95 \% \mathrm{CI}=0.96-2.73$. Children of alcoholics in the late adolescence period had the chances indicator results of $O R=0.7$ and $95 \% \mathrm{CI}=0.42-1.63$, while in the control group it was $C R=1.45$ and $95 \% \mathrm{CI}=0.86-2.44$. The obtained results prove that in each age group children of non-alcoholics have a three times greater a chance for positive adaptation than do the offspring of parents abusing alcohol.

\section{PERSONALITY DIFFERENCES IN THE DIFFERENTIATED ADAPTATION PROFILES}

The next step in the analysis was to determine whether there are differences between the high-level (1) and low-level (2) adaptation profiles among children of alcoholics in terms of the measured individual predispositions.

\section{Psychological resiliency}

An individual attribute of a person, which can support them in coping with difficult situations resulting from a parent's alcohol addition, is resiliency. It includes a set of personality traits that facilitate the development of adaptation processes in difficult life circumstances. It was assumed that children of alco holics, who cope better with strong, accumulated life distress resulting from disorders of their addicted parent, will demonstrate a higher level of resiliency than would children of alcoholics with the low-level adaptation profile. The hypothesis was tested using the Resiliency Scales for Children and Adolescents (Prince-Embury, 2007), which enabled the assessment of the three components of resiliency: mastery, relatedness and reactivity.

Comparing mean results achieved by children of alcoholics in the field of resiliency, it is clear that there is variation within the discussed profiles, and there are differences between all measured components of psychological resiliency (see Table 3).

Children of alcoholics with high-level adaptation (profile 1) have more personal resources related to resiliency than do children of alcoholics with the lower level of adaptation (profile 2). The former featured a higher level of mastery $\left(M^{1}=60.15\right.$; $S D^{1}=8.9 ; M^{2}=44.96 . S D^{2}=11 ; F(1.267)=340 ; p<0.001$; $d=1.6$, respectively), relatedness $\left(M^{1}=68.03 ; S D^{1}=12\right.$; $M^{2}=50.98 ; S D^{2}=13.8 ; F(1.267)=205.33 ; p<0.001 ;$ $d=1.4$, respectively) and reactivity, defined as strong emotional control $\left(M^{1}=51.65 ; S D^{1}=13.8 ; M^{2}=36.11\right.$; $\left.S D^{2}=12.1 ; F(1.267)=182.90 ; p<0.001 ; d=1.2\right)$.

\section{Strategies of coping with stress}

The ability to cope with stress in an efficient way is a significant element of an individual's response to aggravating or traumatic events. It is indicated more and more frequently that what really matters is not the number and severity of distressing events, but the ability to control behaviours, emotions and cognitive functions in response to stress. Efficient coping strategies determine to a high extent the adaptive effects observed in the development of children and adolescents. This variable was measured using the 'How are you doing?' scale - JSR (Fak sobie radzisz?) by Z. Juczyński and N. Ogińska-Bulik (2009), which enables the analysis of dispositional and situational strategies of coping with stress. Dispositional strategies refer to sets of coping strategies characteristic of an individual, and situational strategies include behaviours demonstrated in a concrete, experienced distressing situation. Each set of strategies includes three scales: Active Coping, Focusing on Emotions and Seeking 
Predispositions and adaptation of children of alcoholics

Table 3

Psychological resiliency with children of alcoholics - inter-profile comparison

\begin{tabular}{|c|c|c|c|c|}
\hline $\begin{array}{l}\text { Attributes } \\
\text { of resiliency }\end{array}$ & $\begin{array}{c}\text { Subgroups - } \\
\text { level of adaptation }\end{array}$ & Mean & $\begin{array}{l}\text { Standard } \\
\text { deviation }\end{array}$ & $N$ \\
\hline \multirow[t]{3}{*}{ mastery } & $\begin{array}{c}\text { profile } 1, \\
\text { high-level adaptation }\end{array}$ & 60.15 & 8.864 & 114 \\
\hline & $\begin{array}{c}\text { profile } 2, \\
\text { low-level adaptation }\end{array}$ & 44.96 & 11.089 & 153 \\
\hline & total & 51.45 & 12.661 & 267 \\
\hline \multicolumn{5}{|c|}{$F=340.68 ; p<0.001$} \\
\hline \multirow[t]{3}{*}{ relatedness } & $\begin{array}{c}\text { profile } 1, \\
\text { high-level adaptation }\end{array}$ & 68.03 & 12.028 & 114 \\
\hline & $\begin{array}{c}\text { profile } 2, \\
\text { low-level adaptation }\end{array}$ & 50.98 & 13.788 & 153 \\
\hline & total & 58.26 & 15.538 & 267 \\
\hline \multicolumn{5}{|c|}{$F=205.33 ; p<0.001$} \\
\hline \multirow[t]{3}{*}{ reactivity } & $\begin{array}{c}\text { profile } 1, \\
\text { high-level adaptation }\end{array}$ & 51.65 & 13.812 & 114 \\
\hline & $\begin{array}{c}\text { profile } 2, \\
\text { low-level adaptation }\end{array}$ & 36.11 & 12.120 & 153 \\
\hline & total & 42.75 & 14.976 & 267 \\
\hline \multicolumn{5}{|c|}{$F=182.90 ; p<0.001$} \\
\hline
\end{tabular}

Social Support. It was assumed that children of alcoholics from profile 1 (high-level adaptation) would present more adaptive strategies of coping with stress in difficult situations than would children of alcoholics with the low-level adaptation profile.

Comparing the results achieved by the subjects from both aforementioned profiles, it turns out that strategies of coping with stress differentiate the distinguished profiles only partially (see Table 4). There are statistically significant differences between selected situational and dispositional coping strategies. However, the differences are not huge. Children of alcoholics with the high-level adaptation profile are featured by greater flexibility in terms of active strategies of coping with stress $\left(M^{1}=6.65 ; S D^{1}=3.01 ; M^{2}=5.07 ; S D^{2}=3 ; F(1.267)=46.971 ;\right.$ $p<0.1 ; d=0.4)$; they also apply these strategies more often in everyday situations $\left(M^{1}=6.67 ; S D^{1}=3.4\right.$; $M^{2}=5.05 ; S D^{2}=3.33 ; F(1.267)=45.289 ; p<0.001$; $d=0.3$ ). When confronted with everyday stress, they also take advantage of social support more frequently $\left(M^{1}=5.46 ; S D^{1}=3 ; M^{2}=5.07 ; S D^{2}=3.3 ; F(1.267)=26.300\right.$; $p<0.001 ; d=0.6)$. Meanwhile, children of alcoholics with low-level adaptation (profile 2) are featured by greater flexibility in terms of strategies related to focusing on emotions $\left(M^{1}=4.95 ; S D^{1}=3.1 ; M^{2}=5.77\right.$; $\left.S D^{2}=3.2 ; F(1.267)=20.228 ; p<0.001 ; d=0.3\right)$. Nonetheless, the revealed difference is not huge.

\section{Attachment patterns}

Attachment, developed from birth on the basis of complex, social interaction between a child and a caretaker, determines the functioning of an individual. It affects significantly a child's self-assessment, social competences, behaviour in difficult situations and coping with life distress. The quality of attachment is significant for personal development and intermediates in outlining its more or less adaptive paths. It was assumed in the presented research that children of alcoholics with the high-level adaptation profile would demonstrate safer attachment patterns than would their less adaptive peers. The variable was measured using the Inventory of Parent and Peer Attachment by Armsden and Greenberg (1987), which enables the assessment of the internal attachment patterns - especially in terms of the attachment figures as sources of safe attachment. This tool enables the analysis of results in four dimensions: attachment bond, degree of mutual trust, quality of communication and the extent of anger and alienation to/from the mother and father.

Comparison of the variables gave the following results: the attachment patterns indicate that there are significant differences in terms of both patterns developed in the relation with the mother and the father (see Table 5). The subjects from alcohol prob- 
Table 4

Strategies of coping with stress with children of alcoholics - inter-profile comparison

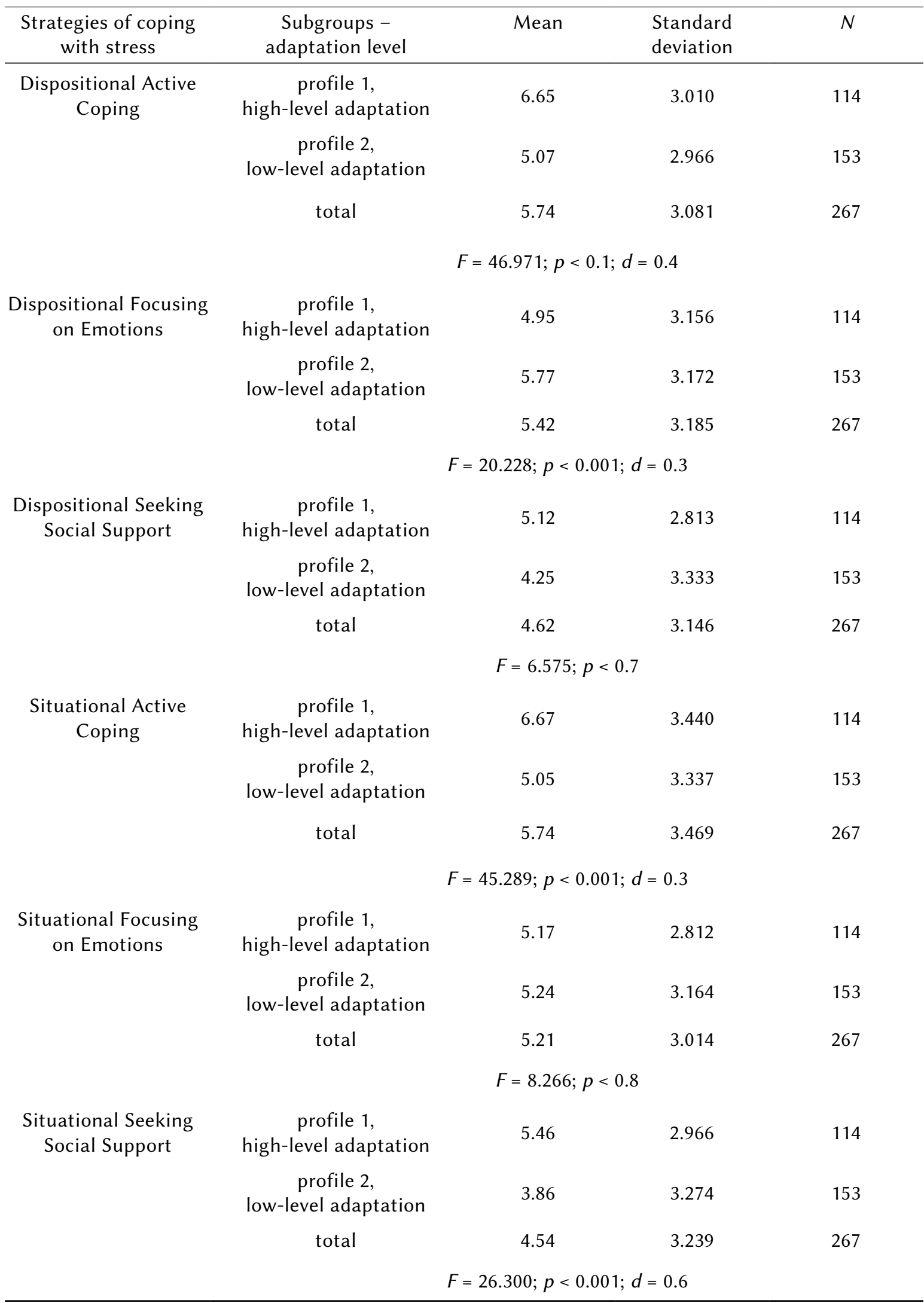


Table 5

Attachment patterns with children of alcoholics - inter-profile comparison

\begin{tabular}{|c|c|c|c|c|}
\hline Attachment patterns & $\begin{array}{c}\text { Subgroups - } \\
\text { adaptation level }\end{array}$ & Mean & $\begin{array}{l}\text { Standard } \\
\text { deviation }\end{array}$ & $N$ \\
\hline \multirow[t]{4}{*}{ bond, mother } & $\begin{array}{c}\text { profile 1, } \\
\text { high-level adaptation }\end{array}$ & 37.63 & 6.902 & 114 \\
\hline & $\begin{array}{c}\text { profile } 2, \\
\text { low-level adaptation }\end{array}$ & 30.34 & 7.249 & 153 \\
\hline & total & 33.45 & 7.958 & 267 \\
\hline & \multicolumn{4}{|c|}{$F=140.36 ; p<0.001 ; d=1$} \\
\hline \multirow[t]{4}{*}{ trust, mother } & $\begin{array}{c}\text { profile } 1, \\
\text { high-level adaptation }\end{array}$ & 38.18 & 6.696 & 114 \\
\hline & $\begin{array}{c}\text { profile } 2, \\
\text { low-level adaptation }\end{array}$ & 29.82 & 8.825 & 153 \\
\hline & total & 33.39 & 8.986 & 267 \\
\hline & \multicolumn{4}{|c|}{$F=141.85 ; p<0.001 ; d=1.3$} \\
\hline \multirow[t]{4}{*}{$\begin{array}{l}\text { communication, } \\
\text { mother }\end{array}$} & $\begin{array}{c}\text { profile } 1, \\
\text { high-level adaptation }\end{array}$ & 35.17 & 6.976 & 114 \\
\hline & $\begin{array}{c}\text { profile } 2, \\
\text { low-level adaptation }\end{array}$ & 24.48 & 7.626 & 153 \\
\hline & total & 29.04 & 9.052 & 267 \\
\hline & \multicolumn{4}{|c|}{$F=203 ; p<0.001 ; d=1.5$} \\
\hline \multirow[t]{4}{*}{ alienation, mother } & $\begin{array}{c}\text { profile } 1, \\
\text { high-level adaptation }\end{array}$ & 12.66 & 4.296 & 114 \\
\hline & $\begin{array}{c}\text { profile } 2 \\
\text { low-level adaptation }\end{array}$ & 17.15 & 4.673 & 153 \\
\hline & total & 15.23 & 5.028 & 267 \\
\hline & \multicolumn{4}{|c|}{$F=119.24 ; p<0.001 ; d=1.2$} \\
\hline \multirow[t]{4}{*}{ bond, father } & $\begin{array}{c}\text { profile } 1, \\
\text { high-level adaptation }\end{array}$ & 28.18 & 9.229 & 114 \\
\hline & $\begin{array}{c}\text { profile } 2, \\
\text { low-level adaptation }\end{array}$ & 22.99 & 8.774 & 153 \\
\hline & total & 25.21 & 9.315 & 267 \\
\hline & \multicolumn{4}{|c|}{$F=81.968 ; p<0.001 ; d=0.6$} \\
\hline \multirow[t]{4}{*}{ trust, father } & $\begin{array}{c}\text { profile } 1, \\
\text { high-level adaptation }\end{array}$ & 28.68 & 10.177 & 114 \\
\hline & $\begin{array}{c}\text { profile } 2, \\
\text { low-level adaptation }\end{array}$ & 23.10 & 9.442 & 153 \\
\hline & total & 25.48 & 10.129 & 267 \\
\hline & \multicolumn{4}{|c|}{$F=68.805 ; p<0.001 ; d=0.5$} \\
\hline
\end{tabular}


Table 5

(Table 5 continued)

\begin{tabular}{|c|c|c|c|c|}
\hline Attachment patterns & $\begin{array}{c}\text { Subgroups - } \\
\text { adaptation level }\end{array}$ & Mean & $\begin{array}{l}\text { Standard } \\
\text { deviation }\end{array}$ & $N$ \\
\hline \multirow[t]{4}{*}{ communication, father } & $\begin{array}{c}\text { profile } 1, \\
\text { high-level adaptation }\end{array}$ & 24.62 & 8.411 & 114 \\
\hline & $\begin{array}{c}\text { profile } 2, \\
\text { low-level adaptation }\end{array}$ & 20.57 & 8.677 & 153 \\
\hline & total & 22.30 & 8.781 & 267 \\
\hline & \multicolumn{4}{|c|}{$F=70.039 ; p<0.001 ; d=0.5$} \\
\hline \multirow[t]{4}{*}{ alienation, father } & $\begin{array}{c}\text { profile } 1, \\
\text { high-level adaptation }\end{array}$ & 18.87 & 5.384 & 114 \\
\hline & $\begin{array}{c}\text { profile } 2, \\
\text { low-level adaptation }\end{array}$ & 20.50 & 5.076 & 153 \\
\hline & total & 19.80 & 5.262 & 267 \\
\hline & \multicolumn{4}{|c|}{$F=60.776 ; p<0.001 ; d=0.4$} \\
\hline
\end{tabular}

lem families with the high-level adaptation profile (profile 1) declare a stronger bond with the mother than children of alcoholics with the low-level adaptation profile (profile 2) $\left(M^{1}=37.63 ; S D^{1}=6.9\right.$; $M^{2}=30.34 ; S D^{2}=7.2 ; F(1.267)=140.36 ; p<0.001$; $d=1)$, greater trust $\left(M^{1}=38.18 ; S D^{1}=6.7 ; M^{2}=29.82\right.$; $\left.S D^{2}=8.8 ; F(1.267)=141.856 ; p<0.001 ; d=1.3\right)$, better communication $\left(M^{1}=35.17 ; S D^{1}=6.9 ; M^{2}=24.48\right.$; $\left.S D^{2}=7.6 ; F(1.267)=203 ; p<0.001 ; d=1.5\right)$ and lower level of alienation and anger $\left(M^{1}=12.16 ; S D^{1}=4.3\right.$; $M^{2}=17.15 ; S D^{2}=4.7 ; F(1.267)=119.246 ; p<0.001$; $d=1.2$ ). The differences are significant.

Compared to children of alcoholics with the low-level adaptation profile (profile 2), the patterns of attachment to the father of children of alcoholics with the high-level adaptation profile (profile 1) are characterised by a significantly stronger bond $\left(M^{1}=28.18 ; S D^{1}=9.2 ; M^{2}=22.99 ; S D^{2}=8.7 ; F(1.267)=\right.$ $=81.968 ; p<0.001 ; d=0.6)$, greater trust $\left(M^{1}=26.68\right.$; $S D^{1}=10.17 ; M^{2}=23.1 ; S D^{2}=9.4 ; F(1.267)=68.805$; $p<0.001 ; d=0.5)$, better communication $\left(M^{1}=24.62\right.$; $S D^{1}=8.4 ; M^{2}=20.57 ; S D^{2}=8.67 ; F(1.267)=70.039$; $p<0.001 ; d=0.5)$ and lower level of alienation and anger $\left(M^{1}=18.87 ; S D^{1}=5.38 ; M^{2}=20.5 ; S D^{2}=5.08\right.$; $F(1.267)=60.776 ; p<0.001 ; d=0.4)$. However, the difference is smaller than in the case of the patterns of attachment to the mother.

\section{Temperament}

Temperament is a significant personal resource of a child, important in the development of positive adaptation under conditions of intense life distress, which are characteristic of an alcohol problem family. There is no unequivocal approach in psychology as far as adaptive functions of temperament are concerned. The terms 'good' or 'bad' temperament are often encountered in empirical studies, which often refer to the assessment of temperament in terms of its adaptive abilities. Many researchers are inclined to agree that temperament in itself does not develop positive or negative adaptation but is a factor that may determine adaptive processes in the course of an individual's development.

In this study it was assumed that children from alcohol problem families with the high-level adaptation profile (profile 1) would demonstrate more positive features of temperament, than would children of alcoholics with the low-level adaptation profile (profile 2). The EAS Temperament Survey by A.H. Buss and R. Plomin, Polish adaptation by W. Oniszczenko (1997), was used to assess temperament. This survey includes various temperamental dimensions for different age groups. In the school age the following dimensions were evaluated: emotionality (E), activity (A), sociability (TS) and shyness (N), and in the group of adolescents and late adolescents: distress $(\mathrm{N})$, fear $(\mathrm{S})$, anger (Z), activity (A) and sociability (T).

Comparing the differentiated adaptation profiles in terms of temperament, it turned out that there is a significant difference within the profiles considering all measured features. Children of alcoholics in school age (see Table 6) with the high-level adaptation profile (profile 1), compared to children of alcoholics with the low-level adaptation profile (profile 2), were less emotional $\left(M^{1}=11.46 ; S D^{1}=4.94\right.$; $M^{2}=15.16 ; S D^{2}=3.8 ; F(1.267)=36.891 ; p<0.001 ;$ $d=1.1)$ and shy $\left(M^{1}=8.86 ; S D^{1}=3.4 ; M^{2}=11.25\right.$; $\left.S D^{2}=5.1 ; F(1.267)=26.824 ; p<0.001 ; d=0.7\right)$, and more active $\left(M^{1}=18.34 ; S D^{1}=4.58 ; M^{2}=13.75\right.$; $\left.S D^{2}=4.78 ; F(1.267)=20.193 ; p<0.001 ; d=0.8\right)$ and sociable $\left(M^{1}=18.37 ; S D^{1}=3.66 ; M^{2}=13.75 ; S D^{2}=4.78\right.$; $F(1.267)=27.432 ; p<0.001 ; d=1.4)$. The difference is significant. 
Table 6

Temperament features with children of alcoholics in school age - inter-profile comparison

\begin{tabular}{|c|c|c|c|c|}
\hline $\begin{array}{l}\text { Temperament } \\
\text { features }\end{array}$ & $\begin{array}{c}\text { Subgroups - } \\
\text { adaptation level }\end{array}$ & Mean & $\begin{array}{l}\text { Standard } \\
\text { deviation }\end{array}$ & $N$ \\
\hline \multirow[t]{4}{*}{ emotionality } & $\begin{array}{c}\text { profile } 1 \\
\text { high-level adaptation }\end{array}$ & 11.46 & 4.943 & 35 \\
\hline & $\begin{array}{c}\text { profile } 2, \\
\text { low-level adaptation }\end{array}$ & 15.16 & 3.799 & 55 \\
\hline & total & 13.72 & 4.625 & 90 \\
\hline & \multicolumn{4}{|c|}{$F=36.891 ; p<0.001 ; d=1.1$} \\
\hline \multirow[t]{4}{*}{ activity } & $\begin{array}{c}\text { profile } 1, \\
\text { high-level adaptation }\end{array}$ & 18.34 & 4.576 & 35 \\
\hline & $\begin{array}{c}\text { profile } 2 \\
\text { low-level adaptation }\end{array}$ & 14.58 & 5.080 & 55 \\
\hline & total & 16.04 & 5.201 & 90 \\
\hline & \multicolumn{4}{|c|}{$F=20.193 ; p<0.001 ; d=0.8$} \\
\hline \multirow[t]{4}{*}{ sociability } & $\begin{array}{c}\text { profile } 1, \\
\text { high-level adaptation }\end{array}$ & 18.37 & 3.663 & 35 \\
\hline & $\begin{array}{c}\text { profile } 2, \\
\text { low-level adaptation }\end{array}$ & 13.75 & 4.781 & 55 \\
\hline & total & 15.54 & 4.913 & 90 \\
\hline & \multicolumn{4}{|c|}{$F=27.432 ; p<0.001 ; d=1.4$} \\
\hline \multirow[t]{4}{*}{ shyness } & $\begin{array}{c}\text { profile } 1, \\
\text { high-level adaptation }\end{array}$ & 8.86 & 3.414 & 35 \\
\hline & $\begin{array}{c}\text { profile } 2, \\
\text { low-level adaptation }\end{array}$ & 11.25 & 5.114 & 55 \\
\hline & total & 10.32 & 4.659 & 90 \\
\hline & \multicolumn{4}{|c|}{$F=26.824 ; p<0.001 ; d=0.7$} \\
\hline
\end{tabular}

Comparing temperament features in both adaptation groups of children of alcoholics in adolescence and late adolescence (see Table 7), it can be observed that individuals with the high-level adaptation profile (profile 1) are characterised by a lower level of negative emotionality, compared to children of alcohol families with the low-level adaptation profile (profile 2), including distress $\left(M^{1}=8.92\right.$; $S D^{1}=3.14 ; M^{2}=12.30 ; S D^{2}=3.85 ; F(1.267)=95.235$; $p<0.001 ; d=1.3)$, fear $\left(M^{1}=9.0 ; S D^{1}=3.62 ; M^{2}=10.76\right.$; $\left.S D^{2}=3.88 ; F(1.267)=16.690 ; p<0.001 ; d=0.6\right)$ and anger $\left(M^{1}=9.56 ; S D^{1}=3.84 ; M^{2}=12.81 ; S D^{2}=4.03\right.$; $F(1.267)=54.588 ; p<0.001 ; d=0.8)$. The differences within profiles refer also to other temperament features: the results were significantly higher for children of alcoholics with the high-level adaptation profile, in terms of activity $\left(M^{1}=14.05 ; S D^{1}=3.5\right.$; $M^{2}=11.44 ; S D^{2}=4.84 ; F(1.267)=18.444 ; p<0.001 ;$ $d=0.8)$ and sociability $\left(M^{1}=15.52 ; S D^{1}=3.6 ; M^{2}=11.55\right.$; $\left.S D^{2}=4.56 ; F(1.267)=45.277 ; p<0.001 ; d=1.1\right)$.
To summarize the obtained data, it should be stated that the family, in a significant and clear way, connected with the mental health of children and adolescents. Children of alcoholics are a high-risk group in terms of the emergence of adaptive problems, both those related to the occurrence of psychopathological symptoms and those related to difficulties in the implementation of developmental tasks and reduced life satisfaction. Thus it can be concluded that the dysfunctionality of a family resulting from a parent's alcohol problem is an important risk factor conditioning the development of psychological problems (in the form of their externalization and internalization).

Meanwhile, the obtained results indicate that children of alcoholics are a heterogenic group, in which the appearance of difficulties in adapting to the living conditions is probabilistic, not deterministic. Approximately $35-40 \%$ of them showed good adaptation to the living conditions, low levels of psychopathology, 
Table 7

Temperament features of children of alcoholics in adolescence and late adolescence - inter-profile comparison

\begin{tabular}{|c|c|c|c|c|}
\hline $\begin{array}{c}\text { Temperament } \\
\text { features }\end{array}$ & $\begin{array}{l}\text { Subgroups - } \\
\text { mental health }\end{array}$ & Mean & $\begin{array}{l}\text { Standard } \\
\text { deviation }\end{array}$ & $N$ \\
\hline \multirow[t]{4}{*}{ distress } & $\begin{array}{c}\text { profile } 1, \\
\text { high-level adaptation }\end{array}$ & 8.92 & 3.141 & 79 \\
\hline & $\begin{array}{c}\text { profile } 2, \\
\text { low-level adaptation }\end{array}$ & 12.30 & 3.851 & 98 \\
\hline & total & 10.79 & 3.921 & 177 \\
\hline & \multicolumn{4}{|c|}{$F=95.235 ; p<0.001 ; d=1.3$} \\
\hline \multirow[t]{4}{*}{ fear } & $\begin{array}{c}\text { profile } 1, \\
\text { high-level adaptation }\end{array}$ & 9.00 & 3.627 & 79 \\
\hline & $\begin{array}{c}\text { profile } 2, \\
\text { low-level adaptation }\end{array}$ & 10.76 & 3.880 & 98 \\
\hline & total & 9.97 & 3.859 & 177 \\
\hline & \multicolumn{4}{|c|}{$F=16.690 ; p<0.001 ; d=0.6$} \\
\hline \multirow[t]{4}{*}{ anger } & $\begin{array}{c}\text { profile } 1, \\
\text { high-level adaptation }\end{array}$ & 9.56 & 3.842 & 79 \\
\hline & $\begin{array}{c}\text { profile } 2, \\
\text { low-level adaptation }\end{array}$ & 12.81 & 4.035 & 98 \\
\hline & total & 11.36 & 4.259 & 177 \\
\hline & \multicolumn{4}{|c|}{$F=54.588 ; p<0.001 ; d=0.8$} \\
\hline \multirow[t]{4}{*}{ activity } & $\begin{array}{c}\text { profile } 1, \\
\text { high-level adaptation }\end{array}$ & 14.05 & 3.508 & 79 \\
\hline & $\begin{array}{c}\text { profile } 2, \\
\text { low-level adaptation }\end{array}$ & 11.44 & 4.846 & 98 \\
\hline & total & 12.60 & 4.482 & 177 \\
\hline & \multicolumn{4}{|c|}{$F=18.444 ; p<0.001 ; d=0.8$} \\
\hline \multirow[t]{4}{*}{ sociability } & $\begin{array}{c}\text { profile } 1, \\
\text { high-level adaptation }\end{array}$ & 15.52 & 3.601 & 79 \\
\hline & $\begin{array}{c}\text { profile } 2, \\
\text { low-level adaptation }\end{array}$ & 11.55 & 4.505 & 98 \\
\hline & total & 13.32 & 4.566 & 177 \\
\hline & \multicolumn{4}{|c|}{$F=45.277 ; p<0.001 ; d=1.1$} \\
\hline
\end{tabular}

good levels of coping with the requirements of the given development stage and a high sense of life satisfaction. Nevertheless, the results of this study show that children of alcoholics are three times less likely to achieve positive adaptation than are their peers brought up in families with no alcohol problem.

The diversity revealed in the study refers not only to developmental results achieved by children of alcoholics, but also to their characteristics in terms of personality traits. What is particularly important is that children of alcoholics, who are characterized by a high level of adaptation, have significantly more psychological resources that help them to cope with the adverse life events. The differences refer to all measured individual predispositions. Individuals with the high-level adaptation profile (profile 1), brought up in families with an alcohol problem, developed more secure attachment patterns, in the relationships with both their father and with their mother. Healthy, well-adjusted individuals have the so-called positive temperament that in the school-age manifests itself as low emotionality and shyness and high sociabili- 
ty and activity, and in further development periods, primarily as a high level of sociability and low tendency to experience negative emotions: distress, fear and anger. At the same time, as the research indicates that children of alcoholics, with high level of adaptation, use active strategies for coping with stress more often in various situations, they also take advantage of social support in difficult life circumstances more often. In terms of psychological resilience processes, an important finding is the diversity of the clinical population concerning resiliency. Children of alcoholics, who cope better with life requirements, are featured by better resources, which facilitate the development of resilience processes such as a sense of mastery, relatedness and strong emotional control.

\section{DISCUSSION}

Studies investigating the potential relation between the history of alcoholism in a family and the impact of addiction-related problems on the adaptation of offspring have been conducted for years (see Sher, 2000). The peak of research in this field dates back to the 1990s. The research results obtained then helped to explain the nature of the problems that children of alcoholics have to face, and to understand the processes and mechanisms that determine the target developmental results in the discussed population (Sher, 1991). A particular point of interest was the determination of which individuals and environmental factors should be taken into consideration when attempting to characterise children of alcoholics. In recent years the primary focus was put on mutual relations between the susceptibility and resilience of children brought up in the shadow of a drinking father (Zucker, Wong, Puttler \& Fitzgerald, 2003; Cierpiałkowska \& Ziarko, 2009; Grzegorzewska, 2013).

What is most noticeable, in previous studies of children of alcoholics the emphasis was shifted from the analysis of the impact of traumatic events and chronic stressors resulting from one of the parents' mental disorder, in the direction of the evaluation process of children's adaptation to challenges and developmental tasks. The adoption of the developmental psychopathology perspective allowed us to broaden the knowledge about the predictors of development, the course of development paths and the results of adaptation, which - as it often turns out - do not confirm the clinically universal knowledge about the deterministic nature of the development of children of alcoholics and its inclination toward psychopathology.

Data obtained during the discussed research enables the aforementioned questions to be answered concerning the positive adaptation of children of alcoholics. The following aspects were investigated: psychological functioning of children and adolescents from families with and without an alcohol problem, their developmental achievement in terms of better or worse adaptation, selected features useful in coping with stress and maintaining mental health. The obtained results confirmed the heterogeneity of the population of children of alcoholics. On the one hand it turned out that they are a risk group, especially prone to develop mental disorders in terms of the intensity of various symptoms and a decrease in the quality of life: smaller satisfaction with life and greater difficulties in attaining developmental tasks. The risk results from greater psychological susceptibility of children of alcoholics to developmental problems and the specificity of their developmental context. On the other hand, the study confirmed that not all children of alcoholics found it difficult to adapt to social requirements. Some of them (about 40\%) coped well with developmental tasks and despite many negative, often accumulated, traumatic events they could find joy, satisfaction and contentment in life.

Searching for an answer to the question as to what makes children of alcoholics more prone to develop psychopathological features, we have not found an unequivocal answer. It remains unclear whether the greater risk is a direct result of the impact of alcoholism, or an intermediate product of genetic and environmental influences, including loose family bonds, poor physical and emotional availability of parents, decreased quality of parental functions or the generally nervous and unstable atmosphere of everyday life, filled with conflicts. The presented results concerning individual predispositions of children of alcoholics confirmed the assumption that the offspring who coped well with life requirements after all, differed from the offspring who revealed adaptive difficulties in terms of basic personality traits; these differences can partially explain the greater susceptibility/resilience to the occurrence of behavioural and emotional problems.

Categories of personality, which seem to be the most closely related to the issue of psychological resilience, include attachment styles, resiliency and temperament. The obtained results indicate clearly that children of alcoholics with a low-level adaptation profile have significantly less secure attachment patterns to their mother and father, and definitely higher intensity of anger and hostility toward them. Referring to Bowlby's concept (1988), the origin of various childhood and adolescence disorders can be explained. The development of emotional regulation and deregulation mechanisms is especially important (some of them facilitate internalisation, and some externalisation, of problems), leading to activation or deactivation of attachment patterns in stress situations. Previous research in this field revealed little if attachment patterns were considered as explanatory factors. It is postulated more and more frequently to consider attachment as an element of resources or 
risk (Iniewicz, 2008), depending on its interaction with other aspects of functioning of an individual, e.g. temperament, reactivity or cross-generation transmission of behavioural patterns. At the same time, the role of a parent in bond development is emphasized, with the assumption that what matters is not the quantity, but quality of parental contact with their child. Decreased accessibility and sensitivity of a parent affects communication with a child the most. It triggers problems with direct expression of thoughts and feelings, develops loose and inconsistent behavioural control patterns, results in difficulties with clear formulation of rules and orders and a lack of reaction or an excessive reaction to their disobedience. Distorted relations and difficulties with adequate reaction lead to the perception of a parent as unavailable and decrease a child's sense of safety. Consequently anger, hostility and fear intensify and a child develops a defensive attitude. If a parent's response does not confirm recognition of the signal of a child's suffering and he/she does not react in an appropriate, sensitive manner, the child will find it difficult to control his/her own painful states, and hence regulate his/her emotional states. Inadequate, intrusive reactions of a parent lead to the intensification of psychopathological symptoms, despite parents' effort to build positive emotional relations with their child (Fonagy \& Target, 1997, Radziwiłłowicz, 2011). The discussed relations were confirmed by the study results. Children of alcoholics with a high-level adaptation profile were featured by safer attachment patterns, which may suggest that their parents were more adequate and emotionally accessible in their early years.

Another personality trait, which also seems to be strongly related to mental health and resilience, is a dynamic feature called psychological resiliency (Ogińska-Bulik \& Juczyński, 2011). Resiliency is a significant personality trait, enhancing health (OgińskaBulik, 2012). Research has proven that children with greater resiliency develop weaker psychopathological symptoms, have a higher level of autonomy and self-trust and better skills necessary in everyday life (see Ogińska-Bulik \& Juczyński, 2011, op. cit.). What is more, Prince-Embury (2007) emphasizes that resiliency is a quality which helps young people adapt to difficult life circumstances, e.g. experience of abuse or parents' divorce - events which often occur in families with alcohol problems (see Johnson, 2002). The analysis of the obtained results enables us to draw the conclusion that lower psychological resiliency among children of alcoholics decreases their adaptation level.

The research results have also confirmed the hypothesis that individual predispositions protecting children of alcoholics from problems also include effective strategies of coping with stress. Children of alcoholics with the high-level adaptation profile attempted to deal with problems and sought solutions despite difficulties more often. They also sought support and help of the others more frequently. This is consistent with the results of another empirical study in this field, which confirms that adaptive coping styles are those which prefer active problem solving, in contrast to strategies focused on negative emotions, e.g. anger or avoidance. Young people who are oriented at more active coping strategies abuse psychoactive substances less often and/or have more pro-social peers (Wills et al., 2001; Ogińska-Bulik \& Juczyński, 2011). Due to the fact that this impact happens to be stronger, if a teenager experiences intensified life distress, it can be assumed that more active coping strategies buffer the relation between risk and risky behaviours. It is also possible that children with more active coping strategies gather information and consider alternative behaviours more often before taking an action. It is a kind of self-control, which protects a child from his/her will to experiment as a way to cope with difficult situations (Wills et al., 2001).

The personality category that seems the most loosely related to the status of children of alcoholics is temperament (Cloninger, 1987), which includes such features as impulsiveness, negative emotionality and sociability. The results of numerous empirical studies (see Sher, 1991; Windle, 1990) indicate that these traits feature children of alcoholics in a significant way (although the strength of association is not large). Meanwhile, the same features turned out to be the strongest predictors of the development of alcoholism, which makes children of alcoholics especially susceptible to addictions (Trull \& Sher, 1994). Although contemporary results of studies on temperamental differences between children of alcoholics and non-alcoholics are not unequivocal (see Grzegorzewska, 2011), the presented research has confirmed the assumption that temperamental features may be useful in explaining the origins of individual differences in the development of children and adolescents, especially in terms of adaptation and attainment of developmental tasks (Bates et al., 1991). The high scores in negative emotionality and low scores in activity and sociability achieved by children of alcoholics with a low-level adaptation profile may be considered to be a constellation of extreme values of certain temperamental features, which may become a potential predictor of behavioural disorders for a child in subsequent stages of his/her development. On a physiological level they are related to low emotional reactivity to adverse symptoms (weak sensitivity of sympathetic nervous system), and on a behavioural level they are demonstrated by a low level of fear in new or threatening situations and decreased sensitivity to punishment signals (Kagan \& Snidman, 1991). The discussed combination of temperamental features may deteriorate development 
and the attainment of developmental tasks at subsequent stages of development, and enhance problems with children and adolescents, both internal (e.g. depression, anxiety) and external (e.g. behavioural disorders, hyperactivity, aggression, destructive, antisocial and psychopathic behaviours). This is consistent with the results of studies conducted on other populations (Blair, 1999; Frick, 2001; Frick et al., 2003; Kochańska, 1993).

Summing up, it can be assumed that children of alcoholics are a heterogenic population. Despite the greater intensity of unfavourable developmental contexts, we can encounter individuals who cope well with social requirements, are well adapted to life and derive satisfaction from it. This is due to their resilience, which is comprised of, inter alia, favourable individual predispositions. In the literature on the subject, which is far from categorical statements, it is often assumed that certain personality traits distinguish children of alcoholics from children of non-alcoholics. The observations discussed in this study incline that we should be more careful in drawing conclusions about the psychological characteristics of children of alcoholics. The obtained study results are consistent with data contained in developmental psychopathology publications, and indicate that children of alcoholics are on the one hand more susceptible to develop disorders, and on the other hand are very heterogenic in terms of developmental results and individual predispositions that shape their personal psychological resilience.

\section{RefERENCES}

Armsden, G.C. \& Greenberg, M.T. (1987). The inventory of parent and peer attachment: relationships to well-being in adolescence. Journal of Youth and Adolescence, 16, 427-454.

Bates, J.E., Bayles, K., Bennet, D.S., Ridge, B. \& Brown, M. (1991). Origins of externalizing behavior problems at eight years of age. In: D. Pepler \& K. Rubin (eds.). The development and treatment of childhood aggression (pp. 93-120). Hillsdale, NJ: Erlbaum.

Blair, R.J.R. (1999). Responsiveness to distress cues in the child with psychopathic tendencies. Personality and Individual Differences, 27, 135-145.

Borucka, A. \& Ostaszewski, K. (2008). Koncepcja resilience. Kluczowe pojęcia i wybrane zagadnienia. Medycyna Wieku Rozwojowego, 12 (2 Pt 1), 587-597.

Bowlby, J. (1988). A secure base. Clinical applications of attachment theory. London: Routledge.

Boyce, W.T., Frank, E., Jensen, P.S., Kessler, R.C., Nelson, C.A. \& Steinberg, L. (1998). Social context in developmental psychopathology: Recommendations for future research from the MacArthur
Network on Psychopathology and Development. Development and Psychopathology, 10, 143-164.

Chassin, L., Pillow, D.R., Curran, P.J., Molina, B.S. \& Barrera, M. Jr. (1993). Relation of parental alcoholism to early adolescent substance use: a test of three mediating mechanisms. Journal of Abnormal Psychology, 102, 3-19.

Cicchetti, D. (2006). Development and psychopathology. In: D. Cicchetti (ed.). Developmental Psychopathology: Theory and Method (pp. 1-23). New York: Wiley.

Cierpiałkowska, L. (2010). Funkcjonowanie dzieci alkoholików - psychospołeczne źródła deficytów i zasobów. W: L. Cierpiałkowska \& M. Ziarko. Psychologia uzależnień - alkoholizm [Psychology of addiction alcoholism] (pp. 253-289). Warszawa: WAiP.

Cierpiałkowska, L. \& Ziarko, M. (2009). Uwarunkowania internalizacji i eksternalizacji zaburzeń u dzieci i młodzieży. Czasopismo Psychologiczne, 15, 71-85.

Cloninger, C.R. (1987). Neurogenetic adaptive mechanisms in alcoholism. Science, 236, 410-416.

Ellis, D., Zucker, R. \& Fitzgerald, H. (2000). Rola oddziaływań rodzicielskich z punktu widzenia rozwoju i oceny ryzyka choroby alkoholowej. Alkohol a zdrowie, 26, 91-111.

Fonagy, P. \& Target, M. (1997). Attachment and reflective function: their role in self-organization. Development and Psychopathology, 9, 679-700.

Frick, P.J. (2001). Effective interventions for children and adolescents with conduct disorder. The Canadian Journal of Psychiatry, 46, 26-37.

Frick, P.J., Cornell, A.H., Bodin, S.D., Dane, H.A., Barry, C.T. \& Loney, B.R. (2003). Callous-unemotional traits and developmental pathways to severe conduct problems. Developmental Psychology, 39, 246-260.

Grzegorzewska, I. (2006). Realizacja zadań rozwojowych okresu dorastania przez dzieci leczacych się alkoholików. Niepublikowana praca doktorska. Poznań: UAM.

Grzegorzewska, I. (2011). Dorastanie w rodzinach z problemem alkoholowym [Adolescence in alcoholic's family]. Warszawa: Scholar.

Grzegorzewska, I. (2013). Odporność psychiczna dzieci alkoholików [Resilience in children of alcoholics]. Warszawa: Scholar.

Higuchi, S., Parrish, K.M., Stinson, F.S., Towle, L.H., Dufour, M.C. \& Harford, T.C. (1992). The association of drinking levels and drinking attitudes among Japanese in Japan and Japanese-Americans in Hawaii and California. Journal of Substance Abuse, 4, 165-177.

Huebner, E.S., Seligson, J.L. \& Valois, R.F. (2003). Preliminary validation of the Brief Multidimensional Students' Life Satisfaction Scale (BMSLSS). Social Indicators Research, 61, 121-145. 
Iniewicz, G. (2008). Zaburzenia emocjonalne dzieci i młodzieży z perspektywy teorii przywiązania. Psychiatria Polska, 5, 671-682.

Jacob, Th. \& Johnson, S. (2000). Styl sprawowania funkcji rodzicielskich a nasilenie problemów alkoholowych. Alkohol a zdrowie, 26, 56-71.

Jones, J.W. (1983). Children of Alcoholics Screening Test (CAST). Chicago, IL: Camelot Unlimited.

Juczyński, Z. \& Ogińska-Bulik, N. (2009). Narzędzia pomiaru stresu i radzenia sobie ze stresem [Tools measurement of stress and coping with stress]. Warszawa: PTP.

Kagan, J. \& Snidman, N. (1991). Temperamental factors in human development. American Psychologist, 46, 856-862.

Kaplan, H.B. (2005). Understanding the concept of resilience. In: S. Goldstein, R. Brooks (eds.). Handbook of Resilience in Children (pp. 39-47). New York, NY: Kluwer Academic.

Kochańska, G. (1993). Toward a synthesis of parental socialization and child temperament in early development of conscience. Child Development, 64, 325-347.

Luthar, S.S., Cicchetti, D. \& Becker B. (2000). The construct of resilience: a critical evaluation and guidelines for future work. Child Development, 71, 543-562.

McGue, M. (2000). Dzieci alkoholików z perspektywy genetyki behawioralnej. Alkohol a zdrowie, 26, 72-90.

Ogińska-Bulik, N. (2012). Prężność jako właściwość osobowości sprzyjająca zdrowiu. In: H. Wrona-Polańska (ed.). Psychologia zdrowia w stużbie człowieka [Health psychology in the human service] (pp. 196-205). Kraków: Wyd. Uniwersytetu Pedagogicznego.

Ogińska-Bulik, N. \& Juczyński, Z. (2011). Prężność u dzieci i młodzieży: charakterystyka i pomiar polska skala SPP-18. Polskie Forum Psychologiczne, 16, 7-28.

Oniszczenko, W. (1997). Kwestionariusz Temperamentu EAS Arnolda H. Bussa i Roberta Plomina. Wersja dla dorostych i dla dzieci. Adaptacja polska. Podręcznik [Temperament questionnaire by A.H. Buss and R. Plomin. The version for children and adults. Polish adaptation. The guide]. Warszawa: PTP.

PARPA (2012). Statystyki. Populacje osób, u których występuja różne kategorie problemów alkoholowych. Retrieved from www.parpa.pl

Prince-Embury, S. (2007). Resiliency Scales for Children and Adolescents: A Profile of Personal Strengths. San Antonio, TX: Harcourt Assessment, Inc.

Radziwiłłowicz, W. (2011). Depresja u dzieci i mtodzieży. Analiza systemu rodzinnego - ujęcie kliniczne [Depression in children and adolescents. Clinical analysis of the family system]. Kraków: Wydawnictwo Impuls.
Sher, K.J. (1991). Children of Alcoholics: A Critical Appraisal of Theory and Research. Chicago: University of Chicago Press.

Sher, K. (2000). Charakterystyka psychologiczna dzieci alkoholików. Alkohol a zdrowie, 26, 164-183.

Sroufe, L.A. (1997). Psychopathology as an outcome of development. Development and Psychopathology, 9, 251-268.

Trull, T.J. \& Sher, K.J. (1994). Relationship between the five-factor model of personality and Axis I disorders in a nonclinical sample. Journal of Abnormal Psychology, 103, 350-360.

Webster, D., Harburg, E., Gleiberman, L., Schork, A. \& DiFranceisco, W. (1989). Familial transmission of alcohol use: I. Parent and adult offspring use over 17 years. Journal of Studies on Alcohol, 50, 557-566

Wills, T.A., Sandy, J.M., Yaeger, A.M., Cleary, S.D. \& Shinar, O. (2001). Coping dimensions, life stress, and adolescent substance use: a latent growth analysis. Journal of Abnormal Psychology, 110, 309-323.

Windle, M. (1990). Temperament and personality attributes of children of alcoholics. In: M. Windle \& J.S. Searles (eds.). Children of alcoholics: Critical perspectives (pp. 187-216). New York: Guilford Press.

Wolańczyk, T. (2002). Zaburzenia emocjonalne i behawioralne u dzieci i mtodzieży szkolnej w Polsce [Externalization and internalization problems of Polish children and adolescents]. Warszawa: Akademia Medyczna.

Zucker, R.A., Kincaid, S.B., Fitzgerald, H.E. \& Bingham, C.R. (1995). Alcohol schema acquisition in pre-schoolers: Differences between children of alcoholics and children of nonalcoholics. Alcoholism: Clinical and Experimental Research, 19, 1-7.

Zucker, R.A., Wong, M.M., Puttler, L.I., Fitzgerald, H.E. (2003). The effects of resilience on developmental outcomes of sons of alcohol. In: S.S. Luthar (ed.). Resilience and Vulnerability (pp. 76-104). New York: Cambridge University Press. 